\title{
Are we meeting the calorific and protein requirement needed in the intensive care setting?
}

\author{
ST Passey*, AKA Abi Musa Asa'ari, M Mendis, B Carr \\ From ESICM LIVES 2015 \\ Berlin, Germany. 3-7 October 2015
}

\section{Introduction}

Establishing nutrition support in a timely manner and by the appropriate route is a priority in the management of the acutely unwell patient. We investigated the total calorific and protein input received in a cohort of patients in the first 7 days of nutrition support during their critical care stay.

\section{Objectives}

We examined the current practice of our intensive care unit (ICU) regarding the amount of calories and protein given to patients during the first days of their critical care stay to assess achievement of energy and protein delivery with respect to consensus guidelines.

\section{Methods}

We collected retrospective data from 50 consecutive intensive care patients from July to November 2014. The inclusion criterion was patient's receiving $\geq 7$ days of prescribed enteral/parenteral feed. Data collected included; patient demographics, type and amount of feed given and total propofol administered in the same period. 3 patients were excluded due to no weight recorded.

We calculated the calorie and protein goal per patient for the 7 day period according to guidelines. [1,2] We then worked out each patient total intake and expressed that as a percentage of the goal target; therefore comparing our practice to the standards. The calories calculated included those provided in propofol.

ASPEN guidelines suggest delivery of $>50$ to $65 \%$ of goal calories (GC) in their first week. GC in the acute phase is $25 \mathrm{kcal} / \mathrm{kg} /$ day. For patients with BMI of $<30$, GC was calculated from actual body weight whereas with BMI $>30$, GC was calculated from ideal body weight. For protein intake ESPEN and ASPEN both recommend $1.5 \mathrm{~g} /$ $\mathrm{kg} /$ day for $\mathrm{BMI}<30.2 \mathrm{~g}$ for 30-40, $2.5 \mathrm{~g}$ for $>40$.

\section{Results}

$87.2 \%$ of patients received $>65 \%$ of their weekly GC and $8.5 \%$ received between 50 to $65 \%$.

In the first 7 days from commencement of feed. Only 1 patient $(2.1 \%)$ received the required amount of protein according to his BMI. $83 \%$ received between 50 and $99 \%$ of the required total.

$60 \%$ of patients were initially prescribed a high protein feed as per local guidelines. $26 \%$ of patients received low protein feed contrary to local guideline.

\section{Conclusions}

$66 \%$ of the patients were started on feed within 48 hours of admission. $95.7 \%$ of our patients were receiving adequate calorific intake according to guidance. $[1,2]$

Provision of protein to our critically ill patients remained low despite predominant use of high protein feed.

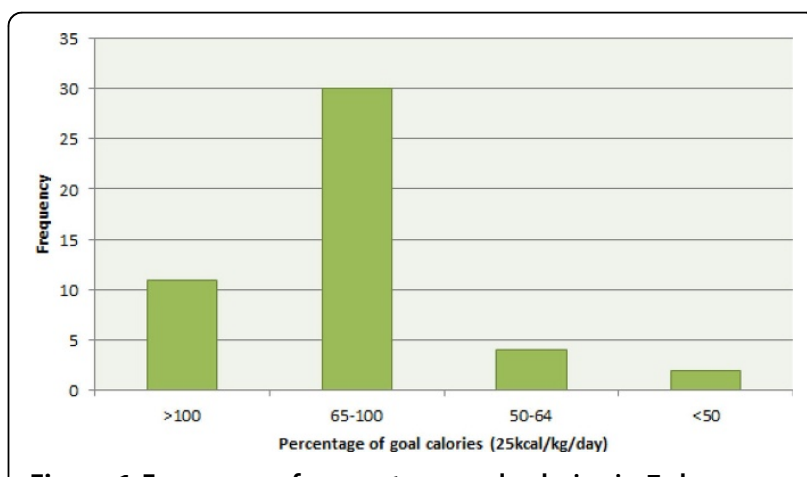

Figure 1 Frequency of percentage goal calories in 7 days. 


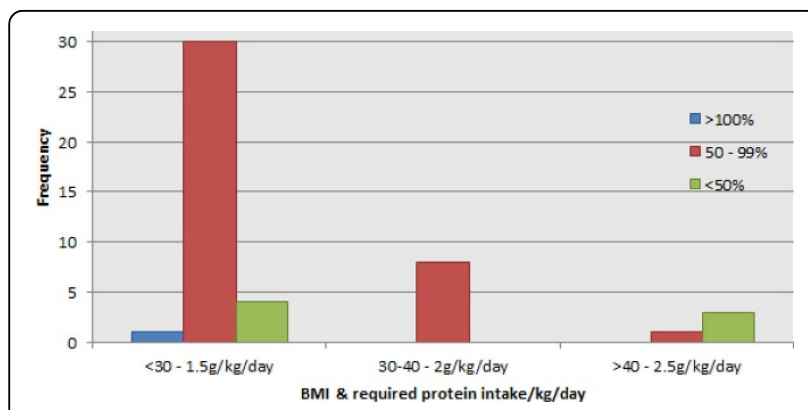

Figure 2 Frequency of percentage goal protein in 7 days according to BMI.

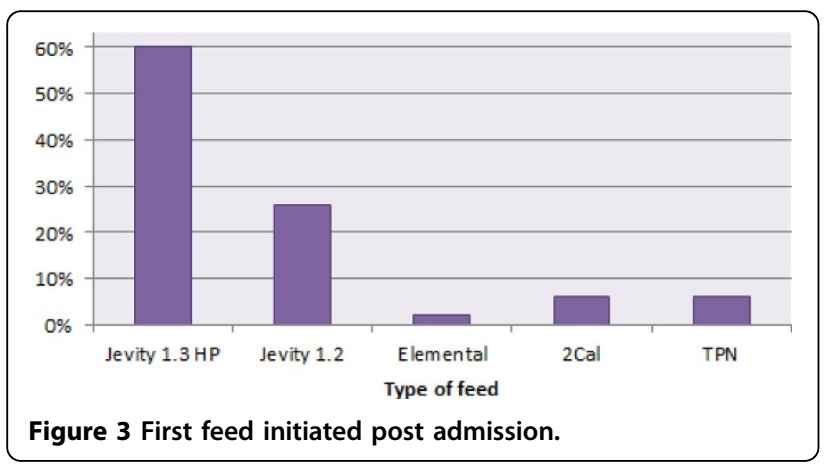

Published: 1 October 2015

\section{References}

1. Singer $P$, Berger MM, Van den Berghe $G$, Biolo G, Calder P, Forbes A, et al: ESPEN guidelines on parenteral nutrition: Intensive care. Clin Nutr 2009, 28(4):387-400.

2. McClave SA, Martindale RG, Vanek WW, McCarthy M, Roberts P, Taylor B, et al: Guidelines for the Provision and Assessment of Nutritional Support Therapy in the Adult Critically III Patient: Society of Critical Care Medicine (SCCM) and AmericanSociety for Parenteral and Enteral Nutrition (A.S.P.E.N.). Journal of Parenteral and Enteral Nutrition 2009, 33(3):277-316.

doi:10.1186/2197-425X-3-S1-A579

Cite this article as: Passey et al:: Are we meeting the calorific and protein requirement needed in the intensive care setting? Intensive Care Medicine Experimental 2015 3(Suppl 1):A579.

\section{Submit your manuscript to a SpringerOpen ${ }^{\mathcal{O}}$ journal and benefit from:}

- Convenient online submission

- Rigorous peer review

- Immediate publication on acceptance

- Open access: articles freely available online

- High visibility within the field

- Retaining the copyright to your article 